\title{
Badanie ciepła radiogenicznego utworów syluru i ordowiku basenu bałtyckiego na podstawie danych geofizyki otworowej i jego relacja z materią organiczną
}

\section{Study of radiogenic heat of the Baltic Basin Silurian and Ordovician formations on the basis of well logging data and its relationship to organic matter}

\author{
Maria Bała, Kamila Wawrzyniak-Guz \\ AGH Akademia Górniczo-Hutnicza im. St. Staszica w Krakowie, Wydział Geologii, Geofizyki i Ochrony Środowiska
}

\begin{abstract}
STRESZCZENIE: W artykule przedstawiono wyniki obliczeń ciepła radiogenicznego (A) wykonanych dla utworów syluru i ordowiku w otworach wiertniczych L-1, K-1, O-2, B-1 i W-1 położonych w basenie bałtyckim. Wykorzystano w tym celu pomiary geofizyki otworowej - spektrometryczne profilowanie gamma (naturalnej promieniotwórczości) oraz pomiary gamma-gamma (profilowanie gęstości objętościowej). Bardzo wysokimi wartościami ciepła radiogenicznego charakteryzowały się osady sylurskich iłowców bitumicznych ogniwa z Jantaru oraz ordowickie ilasto-mułowcowe utwory formacji z Sasina. Są to utwory uznawane za potencjalne sweet spoty z uwagi na podwyższoną zawartość materii organicznej. W obu jednostkach litostratygraficznych zaobserwowano podwyższoną naturalną promieniotwórczość oraz wyraźnie obniżoną gęstość objętościową wywołane obecnością kerogenu. Połączona analiza spektrometrycznego profilowania gamma i profilowania gęstości wykazała, że za wyższą produkcję ciepła radiogenicznego w tych jednostkach odpowiedzialna jest przede wszystkim podwyższona koncentracja uranu. Anomalnie wysokie wartości ciepła radiogenicznego zaznaczały się również w ordowickich iłowcach glaukonitowych formacji ze Słuchowa, w których stwierdzono wyraźny wzrost koncentracji potasu, toru i uranu. Należy zaznaczyć, że utwory czarnych łupków bitumicznych z Jantaru oraz iłowce i mułowce z Sasina charakteryzowały się dużą zmiennością obliczonego parametru A. W prezentowanej pracy przeanalizowano także relacje między obliczonymi wartościami ciepła radiogenicznego a: całkowitym natężeniem promieniowania gamma z pomiaru spektrometrycznego, prędkościami fal podłużnych oraz gęstością objętościową. Zależności określono dla poszczególnych jednostek litostratygraficznych syluru i ordowiku. Podobne relacje ciepła radiogenicznego z profilowaniem gamma zaobserwowano we wszystkich analizowanych otworach z wyjątkiem otworu L-1, w którym sylurskie i ordowickie formacje bogate w kerogen wykazały inną charakterystykę. Zauważono również wyraźne obniżanie się ciepła radiogenicznego ze wzrostem prędkości fal podłużnych. Szczegółowa analiza danych wykazała silne relacje między prędkością a zawartością toru i potasu, które są wskaźnikami minerałów ilastych, oraz zawartością uranu, związanego z obecnością substancji organicznej. Podobny związek pokazujący tendencję obniżania się ciepła radiogenicznego zaobserwowano dla wzrastających wartości gęstości objętościowej analizowanych utworów.
\end{abstract}

Słowa kluczowe: ciepło radiogeniczne, spektrometryczne profilowanie gamma i gamma-gamma, basen bałtycki, geofizyka otworowa, skały macierzyste, hupki gazonośne.

ABSTRACT: The paper presents results of computations of the radioactive heat production (A) for the Silurian and Ordovician rocks in the L-1, K-1, O-2, B-1, and W-1 wells located in the Baltic Basin. For this purpose, well logging data - spectral gamma (intensity of the natural radioactivity) and gamma-gamma (bulk density) logs were used. Silurian deposits of the Jantar Bituminous Black Claystone Member and Ordovician deposits of the Sasino Claystone Formation were characterised by very high values of the radiogenic heat. These units are considered as sweet spots due to a high concentration of organic matter. Increased natural radioactivity and significantly reduced bulk densities caused by the presence of kerogen were observed in both lithostratigraphic units. A joint analysis of the spectral gamma ray log and the density logs showed that the increased radiogenic heat production in these formations was mainly caused by a higher concentration of uranium. Abnormally high values of radiogenic heat were also observed in the Ordovician glauconitic claystones of the Słuchowo Formation, where an increase in potassium, thorium, and uranium concentrations was detected. It should be noted that the deposits of the black claystones of the Jantar Member, and the claystones and mudstones of the Sasino Formations were characterised by high variability of the calculated parameter A. The presented article investigated the relationship between the

Autor do korespondencji: Kamila Wawrzyniak-Guz, e-mail: wawrzyni@agh.edu.pl

Artykuł nadesłano do Redakcji 22.05.2019 r. Zatwierdzono do druku 22.08.2019 r. 
calculated values of radiogenic heat and natural radioactivity, the velocity of longitudinal waves, as well as between bulk density. The relations were determined for the Silurian and Ordovician deposits. Similar relations between the radiogenic heat and the gamma ray log were observed in all wells except the L-1 well, in which Silurian and Ordovician formations rich in kerogen revealed a different characteristic. A significant decrease in radiogenic heat values was observed with the increase in P wave velocity. Detailed data analyses showed strong relationships between velocity and the content of thorium and potassium, which are the indicators of clay minerals, but also the content of uranium, which is associated with the organic matter presence. A similar relation showing a tendency of decreasing radiogenic heat was obtained for increased bulk densities of the formations.

Key words: radiogenic heat, spectral gamma ray and gamma-gamma logs, Baltic Basin, well logging, source rocks, gas shales.

\section{Wprowadzenie}

Badanie ciepła radiogenicznego skał na podstawie spektrometrycznych pomiarów otworowych i laboratoryjnych stanowi cenne źródło informacji o zdolności skał macierzystych do akumulacji węglowodorów. Skała macierzysta po osiągnięciu odpowiedniej dojrzałości termicznej może transformować nagromadzoną substancję organiczną $\mathrm{w}$ węglowodory i przekazywać je do sąsiednich warstw zbiornikowych. Korelacja ciepła radiogenicznego z parametrami skał, wyznaczonymi na podstawie profilowań akustycznych czy neutronowych, może dostarczyć unikalnych informacji wykorzystywanych w modelowaniach basenów naftowych.

Z punktu widzenia poszukiwań złóż ropy i gazu skały charakteryzujące się wysoką produkcją ciepła radiogenicznego, a posiadające podwyższoną zawartość uranu są najczęściej skałami macierzystymi dla węglowodorów. Odtworzenie historii termicznej skał jest ważnym elementem rekonstrukcji procesów generowania i ekspulsji węglowodorów (Kotarba et al., 2006).

\section{Informacje geologiczne}

Analizę ciepła radiogenicznego wykonano w pięciu otworach: O-2, L-1, K-1, B-1 i W-1. Wszystkie usytuowane są w północnej części basenu bałtyckiego, będącego częścią systemu dolnopaleozoicznych basenów sedymentacyjnych, rozciągającego się wzdłuż zachodniego skłonu kratonu wschodnioeuropejskiego (m.in. Poprawa, 2010; Porębski et al., 2013; Podhalańska et al., 2016). Pomiary geofizyki otworowej wykorzystane w niniejszych obliczeniach wykonano na przestrzeni lat 2012-2014 przy użyciu nowoczesnej aparatury i odpowiedniego zestawu sond. Na rysunku 1 przedstawiono orientacyjne położenie otworów, w których zostało obliczone ciepło radiogeniczne. Umiejscowione są one wzdłuż linii NNW-SSE. Wszystkie otwory zostały odwiercone do osadów kambru środkowego.

Przedmiotem badań były ordowickie i sylurskie łupki zawierające iłowce, iłowce pylaste (mułowce) oraz mułowce o niższej zawartości iłów, często wapniste. Węglany występują w nich w postaci cementu lub w formie przewarstwień czy

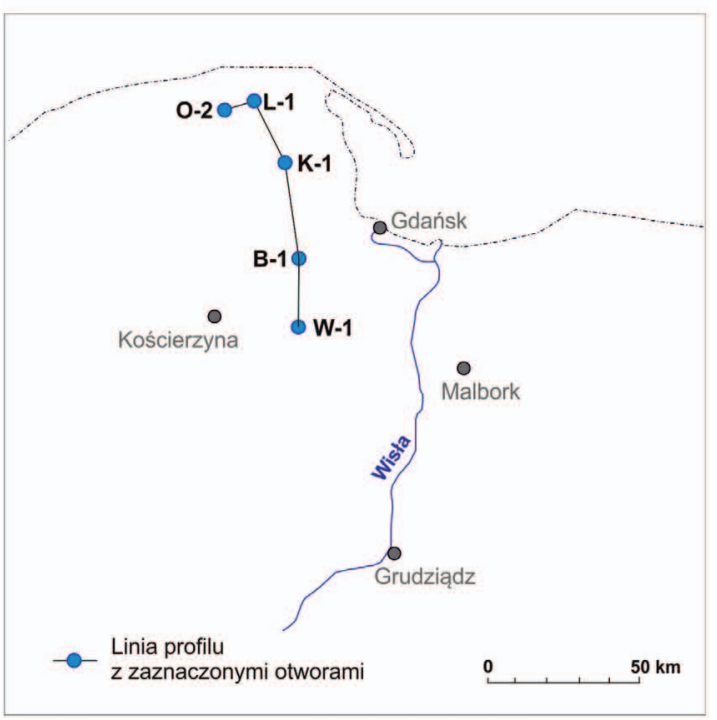

Rys. 1. Orientacyjne położenie otworów, w których obliczano ciepło radiogeniczne, na tle fragmentu mapy Pomorza Wschodniego

Fig. 1. Approximate location of the wells for which the radiogenic heat was calculated against the fragment of the map of Eastern Pomerania

konkrecji. Obecne są również cienkie wtrącenia skał piroklastycznych - bentonitów i tufitów (Podhalańska et al., 2016). Charakterystyczne dla badanych łupków dolnopaleozoicznych jest występowanie rozproszonej lub skupionej w mikrolaminach materii organicznej. Pod względem mineralogicznym analizowane formacje łupkowe zbudowane są przede wszystkim z illitu, struktur mieszanopakietowych typu illit-smektyt i chlorytów, sporadycznie obecny jest kaolinit. W materiale okruchowym występują kwarc oraz skalenie potasowe i plagioklazy. Cement zbudowany jest najczęściej z kalcytu, dolomitu lub innych węglanów, obecne są także piryt i inne związki siarki oraz fosforany (Sikorska-Jaworowska et al., 2016).

Analizowane utwory obejmują takie jednostki litostratygraficzne jak (od najmłodszych do najstarszych):

a) formacja ilowców i ilowców wapnistych z Pucka (sylur, przydol-ludlow);

b) formacja iłowców i mułowców z Kociewia (sylur, ludford-gorst (ludlow));

c) ogniwo mułowców wapnistych Redy, formacja

z Kociewia (sylur, ludlow);

d) formacja ilowców z Pelplina (sylur, ludlow-wenlok); 
e) formacja ilowców z Pasłęka (sylur, górny i środkowy landower);

f) ogniwo iłowców bitumicznych z Jantaru, formacja z Pasłęka (sylur, dolny landower): czarne iłowce bitumiczne z licznym pirytem, $\mathrm{z}$ laminami iłowców wapnistych i gruzłami wapieni marglistych;

g) formacja margli i iłowców z Prabut (ordowik, aszgil);

h) formacja iłowców z Sasina (ordowik, karadok-lanwirn): czarne, ciemnoszare i szarozielone łupki, często bitumiczne, wapniste lub bezwapniste i zsylifikowane z ooidami żelazistymi, liczne wkładki bentonitów, miejscami występują wkładki ciemnoszarych i szarych wapieni marglistych i margli;

i) formacja wapieni $\mathbf{z}$ Kopalina (ordowik, lanwirn-arenig);

j) formacja iłowców z glaukonitem ze Słuchowa (ordowik, arenig).

Przedstawiony podział chrono- i litostratygraficzny oparty jest na publikacjach: Modlińskiego i Szymańskiego (1997), Modlińskiego et al. (2006) oraz Podhalańskiej et al. (2016). Na rysunku 2 schematycznie przedstawiono występowanie poszczególnych jednostek litostratygraficznych w badanych otworach w zakresie głębokości, w którym wykonano obliczenia ciepła radiogenicznego.

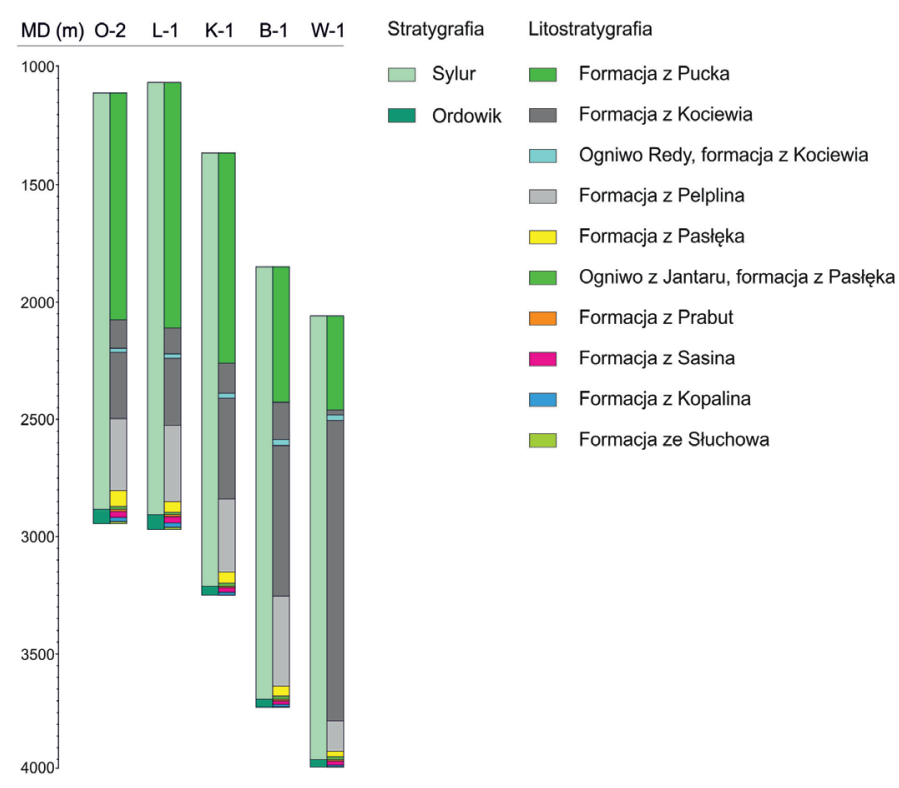

Rys. 2. Schematyczne zestawienie litostratygrafii i interwałów głębokościowych w badanych otworach

Fig. 2. Schematic depiction of the lithostratigraphy and the depth intervals in the investigated wells

Szczególne zainteresowanie, z uwagi na poszukiwania gazu w dolnopaleozoicznych łupkach na terenie Polski, budziło ogniwo czarnych iłowców bitumicznych z Jantaru, którego zasięg stratygraficzny przypada na landower, i stanowiące spągową część formacji iłowców z Pasłęka, oraz formacja iłowców z Sasina, zaliczana do ordowiku (karadok/lanwirn). $\mathrm{W}$ obu wymienionych jednostkach litostratygraficznych badania laboratoryjne wykazały podwyższoną zawartość materii organicznej, co wyróżnia je zdecydowanie od skał otaczających (Dokumentacje wynikowe otworów L-1, O-2, K-1, B-1, W-1).

W ogniwie z Jantaru całkowita zawartość węgla organicznego (TOC) wyznaczona na podstawie badań laboratoryjnych pyrolizy Rock-Eval osiąga wartość do 7,3\% wag. (otwór O-2 - 7,15\% wag., L-1 - 7,3\% wag., K-1 - 4,98\% wag., B- $1-5,08 \%$ wag., $\mathrm{W}-1-5,01 \%$ wag.), natomiast $\mathrm{w}$ formacji z Sasina $-5,95 \%$ wag. (otwór O-2 - 0,99\% wag., L-1 - 4,78\% wag., K-1 - 4,31\% wag., B-1 - 5,95\% wag., W-1 - 5,12\% wag.) (Dokumentacje wynikowe otworów L-1, O-2, K-1, B-1, W-1).

\section{Ciepło radiogeniczne}

W czasie rozpadu promieniotwórczego masa jest przekształcana w energię, a znaczna część tej energii jest zamieniana na ciepło. Wszystkie naturalne izotopy promieniotwórcze wytwarzają ciepło, ale tylko izotopy ${ }^{238} \mathrm{U},{ }^{235} \mathrm{U},{ }^{232} \mathrm{Th} \mathrm{i}{ }^{40} \mathrm{~K}$ mają znaczenie geologiczne (Vilà et al., 2010). Zapewniają one ponad $98 \%$ produkcji ciepła. Izotop ${ }^{235} \mathrm{U}$ ma znacząco krótszy okres półrozpadu niz ${ }^{238} \mathrm{U}$ (odpowiednio około 0,7 miliarda lat i 4,5 miliarda lat) i jest obecnie zredukowany do $0,7 \%$ całkowitego naturalnie występującego uranu. Inne, krótkożyciowe izotopy promieniotwórcze mogły mieć znaczący wkład termiczny we wczesnych stadiach historii Ziemi, ale teraz nie są one wykrywalne. Inne długożyciowe izotopy radioaktywne również istnieją, ale ich tempo zaniku jest tak powolne, że nigdy nie wniosły żadnego znaczącego wkładu w ciepło Ziemi (np. ${ }^{87} \mathrm{Rb}$ z okresem półtrwania wynoszącym około 4 miliardów lat $\mathrm{i}^{147} \mathrm{Sm} \mathrm{z}$ okresem półtrwania około 106 miliardów lat) (Slagstad, 2008)

Podstawowym geologicznym źródłem potasu, uranu i toru są kwaśne skały magmowe. Pierwiastki te występują w minerałach skałotwórczych, takich jak miki i skalenie, oraz w minerałach akcesorycznych, jak np. cyrkon, monacyt $\mathrm{i}$ inne. W procesach wietrzeniowych i sedymentacyjnych minerały te przechodzą niezmienione do skał osadowych bądź ulegają rozkładowi, tworząc nowe minerały, głównie ilaste, z którymi mogą wiązać się pierwiastki promieniotwórcze (Jarzyna et al., 1999; Ellis i Singer, 2008). Procesy te regulowane są parametrami fizykochemicznymi środowiska sedymentacyjnego: stężeniem jonów wodorowych $(\mathrm{pH})$ i potencjałem redukcyjno-utleniającym (Eh).

Zawartości toru i potasu mogą być wykorzystane do oceny zailenia skał, natomiast składowa uranowa, rejestrowana w trakcie profilowania spektrometrycznego gamma (SGR), jest cennym wskaźnikiem obecności substancji organicznej. Skały macierzyste, w których generowały się węglowodory, 
mogą charakteryzować się wyższymi koncentracjami uranu (Jarzyna et al., 1999; Bała i Witek, 2011; Bała i Waliczek, 2012). Wielkość ciepła radiogenicznego A jest determinowana, obok innych parametrów, przez własności termiczne skał. Do najważniejszych prac charakteryzujących powyższe zagadnienia należą prace: Keen'a i Levis'a (1982), Rybacha (1986), Cermaka et al. (1990), Bückera i Rybacha, 1996; McKenny i Sharp'a (1998), Förster i Förster'a (2000) oraz Norden'a i Förster (2006); a w Polsce: Plewy (1988), Ciechanowskiej i Gąsior (2000), Krawiec (2007), Bały i i Witka (2011); Bały i Waliczek (2012).

Ciepło radiogeniczne można obliczyć ze znanego i szeroko stosowanego na świecie wzoru Rybacha (Rybach, 1986):

$$
A=10^{-5} \cdot \rho_{b} \cdot\left(9,52 \cdot \mathrm{C}_{\mathrm{u}}+2,56 \cdot \mathrm{C}_{\mathrm{Th}}+3,48 \cdot \mathrm{C}_{\mathrm{K}}\right)
$$

gdzie:

$A$ - ciepło radiogeniczne $\left[\mu \mathrm{W} / \mathrm{m}^{3}\right]$,

$\rho_{b}-$ gęstość objętościowa skały $\left[\mathrm{kg} / \mathrm{m}^{3}\right]$,

$\mathrm{C}_{\mathrm{U}}, \mathrm{C}_{\mathrm{Th}}, \mathrm{C}_{\mathrm{K}}-$ koncentracje uranu [ppm], toru [ppm]

i potasu [\%].

W równaniu (1) każda wartość koncentracji pierwiastka promieniotwórczego jest mnożona przez pewną liczbę (stałą). Stałe te odzwierciedlają zróżnicowany wkład w produkcję ciepła radiogenicznego. Stała dla uranu $(9,52)$ jest ponad dwukrotnie większa od stałych dla potasu $(3,48)$ lub toru $(2,56)$. Pokazuje dominującą rolę uranu w wytwarzaniu ciepła w porównaniu do toru i potasu. Większość wytwarzanego ciepła radiogenicznego zapewnia głównie rozpad alfa uranu (Mccay, 2014).

\section{Obliczanie ciepła radiogenicznego w badanych formacjach}

Wykorzystując wzór (1), obliczono ciepło radiogeniczne dla utworów syluru i ordowiku w pięciu otworach basenu bałtyckiego (O-2, L-1, K-1, B-1 i W-1). W tabeli 1 przedstawiono wartości średnie oraz minimalne i maksymalne wyznaczonego ciepła radiogenicznego w poszczególnych jednostkach litostratygraficznych dla tych otworów.

Na rysunku 3 pokazano zestawienie danych spektrometrycznych gamma i gamma-gamma, obliczone ciepło radiogeniczne i wartości TOC dla utworów syluru: formacji z Pelplina, z Pasłęka, ogniwa z Jantaru i utworów ordowiku: formacji z Prabut, z Sasina, wapieni z Kopalina i formacji ze Słuchowa

Tablica 1. Minimalne, maksymalne i średnie wartości ciepła radiogenicznego obliczone na podstawie profilowania spektrometrycznego gamma i gęstościowego gamma-gamma w poszczególnych jednostkach litostratygraficznych

Table 1. The minimum, maximum and average values of the radiogenic heat calculated on the basis of the spectral gamma and gammagamma logs in the individual lithostratigraphic units

\begin{tabular}{|c|c|c|c|c|c|c|c|c|c|c|c|}
\hline \multirow{3}{*}{ Stratygrafia } & \multirow{3}{*}{ Litostratygrafia } & \multicolumn{10}{|c|}{ Ciepło radiogeniczne $A\left[\mu \mathrm{W} / \mathrm{m}^{3}\right]$} \\
\hline & & \multicolumn{2}{|c|}{$0-2$} & \multicolumn{2}{|c|}{ L-1 } & \multicolumn{2}{|c|}{ K-1 } & \multicolumn{2}{|c|}{ B-1 } & \multicolumn{2}{|c|}{ W-1 } \\
\hline & & $\begin{array}{l}\min \\
\max \end{array}$ & średnia & $\begin{array}{l}\min \\
\max \end{array}$ & średnia & $\begin{array}{l}\min \\
\max \end{array}$ & średnia & $\begin{array}{l}\min \\
\max \end{array}$ & średnia & $\begin{array}{l}\min \\
\max \end{array}$ & średnia \\
\hline $\begin{array}{c}\text { Sylur } \\
\text { (przydol/ludlow) }\end{array}$ & $\begin{array}{l}\text { Formacja } \\
\text { z Pucka }\end{array}$ & $\begin{array}{l}1,294 \\
2,442\end{array}$ & 1,753 & $\begin{array}{l}0,618 \\
2,604\end{array}$ & 1,757 & $\begin{array}{l}1,038 \\
2,702\end{array}$ & 1,867 & $\begin{array}{l}0,768 \\
2,828\end{array}$ & 1,916 & $\begin{array}{l}0,374 \\
2,489\end{array}$ & 1,921 \\
\hline $\begin{array}{c}\text { Sylur } \\
\text { (ludlow) }\end{array}$ & $\begin{array}{l}\text { Formacja } \\
\text { z Kociewa }\end{array}$ & $\begin{array}{l}1,223 \\
2,422\end{array}$ & 1,900 & $\begin{array}{l}1,242 \\
2,428\end{array}$ & 1,913 & $\begin{array}{l}1,363 \\
2,475\end{array}$ & 1,969 & $\begin{array}{l}1,334 \\
2,448\end{array}$ & 1,981 & $\begin{array}{l}1,187 \\
3,081\end{array}$ & 1,957 \\
\hline $\begin{array}{c}\text { Sylur } \\
\text { (ludlow) }\end{array}$ & Ogniwo Redy & $\begin{array}{l}0,856 \\
1,650\end{array}$ & 1,153 & $\begin{array}{l}0,773 \\
1,837\end{array}$ & 1,163 & $\begin{array}{l}0,861 \\
1,775\end{array}$ & 1,256 & $\begin{array}{l}1,017 \\
1,777\end{array}$ & 1,368 & $\begin{array}{l}1,076 \\
1,951\end{array}$ & 1,457 \\
\hline $\begin{array}{c}\text { Sylur } \\
\text { (ludlow/wenlok) }\end{array}$ & $\begin{array}{l}\text { Formacja } \\
\text { z Pelplina }\end{array}$ & $\begin{array}{l}1,126 \\
2,830\end{array}$ & 2,342 & $\begin{array}{l}1,125 \\
3,006\end{array}$ & 2,329 & $\begin{array}{l}1,130 \\
3,052\end{array}$ & 2,386 & $\begin{array}{l}1,123 \\
3,012\end{array}$ & 2,415 & $\begin{array}{l}1,228 \\
3,070\end{array}$ & 2,193 \\
\hline $\begin{array}{c}\text { Sylur } \\
\text { (landower) }\end{array}$ & $\begin{array}{l}\text { Formacja } \\
\text { z Pasłęka }\end{array}$ & $\begin{array}{l}1,772 \\
3,436\end{array}$ & 2,189 & $\begin{array}{l}1,853 \\
3,769\end{array}$ & 2,204 & $\begin{array}{l}1,866 \\
3,136\end{array}$ & 2,189 & $\begin{array}{l}1,818 \\
2,976\end{array}$ & 2,257 & $\begin{array}{l}1,822 \\
2,859\end{array}$ & 2,253 \\
\hline $\begin{array}{c}\text { Sylur } \\
\text { (landower) }\end{array}$ & Ogniwo z Jantaru & $\begin{array}{l}1,941 \\
5,145\end{array}$ & 3,373 & $\begin{array}{l}2,255 \\
5,010\end{array}$ & 3,392 & $\begin{array}{l}1,850 \\
5,087\end{array}$ & 3,372 & $\begin{array}{l}1,766 \\
5,395\end{array}$ & 3,075 & $\begin{array}{l}1,493 \\
3,771\end{array}$ & 2,319 \\
\hline $\begin{array}{l}\text { Ordowik } \\
\text { (aszgil) }\end{array}$ & $\begin{array}{l}\text { Formacja } \\
\text { z Prabut }\end{array}$ & $\begin{array}{l}1,402 \\
2,869\end{array}$ & 1,732 & $\begin{array}{l}1,338 \\
3,399\end{array}$ & 1,788 & $\begin{array}{l}1,298 \\
2,392\end{array}$ & 1,596 & $\begin{array}{l}1,410 \\
3,483\end{array}$ & 1,719 & $\begin{array}{l}1,518 \\
2,198\end{array}$ & 1,659 \\
\hline $\begin{array}{c}\text { Ordowik } \\
\text { (karadok/lanwirn) }\end{array}$ & $\begin{array}{l}\text { Formacja } \\
\text { z Sasina }\end{array}$ & $\begin{array}{l}1,591 \\
5,347\end{array}$ & 2,603 & $\begin{array}{l}1,854 \\
5,874\end{array}$ & 2,775 & $\begin{array}{l}1,720 \\
9,754\end{array}$ & 3,026 & $\begin{array}{l}1,525 \\
5,551\end{array}$ & 2,824 & $\begin{array}{l}1,250 \\
3,499\end{array}$ & 2,475 \\
\hline $\begin{array}{c}\text { Ordowik } \\
\text { (lanwirn/arenig) }\end{array}$ & $\begin{array}{l}\text { Formacja } \\
\text { z Kopalina }\end{array}$ & $\begin{array}{l}0,640 \\
2,343\end{array}$ & 1,084 & $\begin{array}{l}0,639 \\
2,276\end{array}$ & 1,164 & $\begin{array}{l}0,628 \\
4,187\end{array}$ & 1,080 & $\begin{array}{l}0,582 \\
6,048\end{array}$ & 1,100 & $\begin{array}{l}0,585 \\
1,475\end{array}$ & 0,935 \\
\hline $\begin{array}{l}\text { Ordowik } \\
\text { (arenig) }\end{array}$ & $\begin{array}{c}\text { Formacja } \\
\text { ze Stuchowa }\end{array}$ & $\begin{array}{l}2,491 \\
4,632\end{array}$ & 3,856 & $\begin{array}{l}2,431 \\
4,321\end{array}$ & 3,661 & $\begin{array}{c}8,413 \\
12,022\end{array}$ & 10,320 & $\begin{array}{l}1,609 \\
9,276\end{array}$ & 4,970 & $\begin{array}{r}2,041 \\
22,446\end{array}$ & 5,989 \\
\hline
\end{tabular}



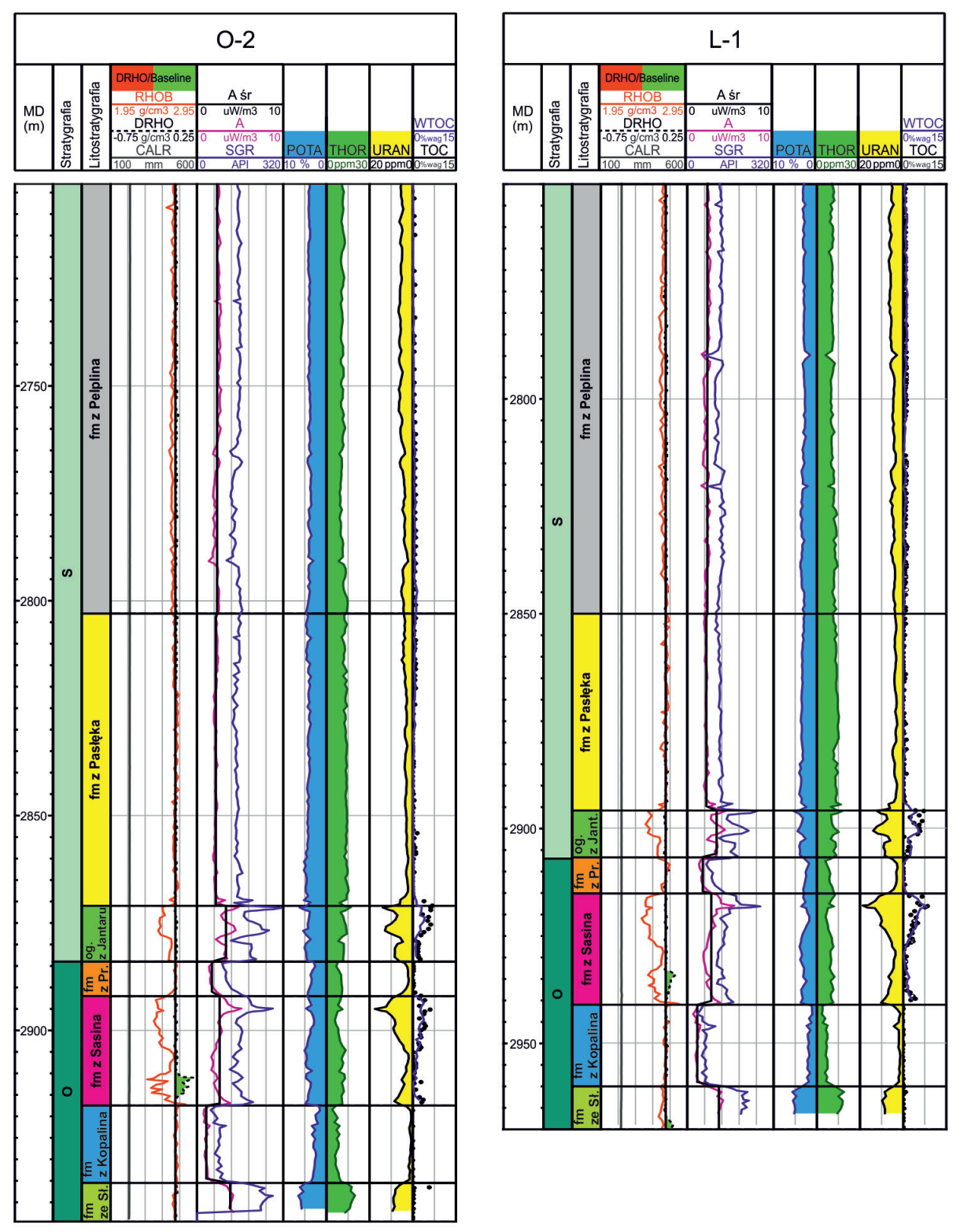

Rys. 3. Wizualizacja wybranych profilowań geofizyki otworowej z obliczonym ciepłem radiogenicznym oraz zawartością całkowitego węgla organicznego w otworach O-2 i L-1: RHOB - profilowanie gamma-gamma (gęstości objętościowej); DRHO - poprawka do profilowania RHOB; CALR - średnica rzeczywista otworu; A - ciepło radiogeniczne; A śr - średnia wartość ciepła radiogenicznego w poszczególnych jednostkach litostratygraficznych; SGR - całkowita intensywność naturalnej promieniotwórczości z pomiaru spektrometrycznego; POTA, THOR, URAN - profilowania koncentracji potasu, toru i uranu ze spektrometrycznej sondy gamma; TOC, WTOC - całkowita zawartość węgla organicznego otrzymana odpowiednio z badań laboratoryjnych i z interpretacji ilościowej profilowań geofizyki otworowej (Dokumentacje otworów L-1, O-2, K-1, B-1, W-1)

Fig. 3. Visualisation of selected well logs along with computed radiogenic heat and total organic carbon in O-2 and L-1 wells: RHOB gamma-gamma log (bulk density log); DRHO - bulk density correction; CALR - caliper; A - radiogenic heat; Aśr - mean value of the radiogenic heat in the individual lithostratigraphic units; SGR - total natural radioactivity from the spectral gamma ray tool; POTA, THOR, URAN - potassium, thorium and uranium concentrations from the spectral gamma ray tool; TOC, WTOC - total organic carbon derived from laboratory tests and quantitative interpretation of well logging data, respectively (L-1, O-2, K-1, B-1, W-1 well documentations)

Tablica 2. Dokładności pomiarów K, Th i U dla sondy Natural Gamma Ray Spectrometry (NGS) i Hostile Environment Natural Gamma Ray Sonde (HNGS) firmy Schlumberger (Schlumberger, 2004)

Table 2. Accuracy of K, Th and U measurements for the Natural Gamma Ray Spectrometry tool (NGS) and Hostile Environment Natural Gamma Ray Sonde (HNGS) from Schlumberger

\begin{tabular}{|l|l|}
\hline \multicolumn{1}{|c|}{ NGS } & \multicolumn{1}{|c|}{ HNGS } \\
\hline \hline K: $\pm 0,4 \%$ (dokładność); 0,25\% (powtarzalność) & $\mathrm{K}: \pm 0,5 \%$ (dokładność); 0,14\% (powtarzalność) \\
Th: $\pm 3,2$ ppm (dokładność); 1,5 ppm (powtarzalność) & Th: $\pm 2 \%$ (dokładność); 0,9 ppm (powtarzalność) \\
U: $\pm 2,3$ ppm (dokładność); 0,9 ppm (powtarzalność) & U: $\pm 2 \%$ (dokładność); 0,4 ppm (powtarzalność) \\
\hline
\end{tabular}


w przykładowo wybranych otworach O-2 i L-1. Wartości TOC obliczone zostały w toku interpretacji ilościowej i według badań laboratoryjnych (Dokumentacje wynikowe otworów: L-1, O-2, K-1, B-1, W-1).

Dokładności obliczonych wartości A zależą od dokładności zmierzonych koncentracji U, Th, K oraz gęstości objętościowej. Dla sondy spektrometrycznej gamma (NGS) i sondy Hostile Environment Natural Gamma Ray (HNGS) firmy Schlumberger wartości te podano w tabeli 2 (Schlumberger, 2004). Dla sond neutron-gamma i gamma-gamma firmy Schlumberger

Tablica 3. Dokładności określenia gęstości objętościowej dla sondy Neutron-Gamma Density (NGD) oraz Gamma-Gamma Density (GGD) firmy Schlumberger (Reichel et al., 2012)

Table 3. Accuracy of determining the bulk density for the Neutron-Gamma Density tool (NGD) and Gamma-Gamma Density tool (GGD) from Schlumberger

\begin{tabular}{|c|c|c|}
\hline \multirow{2}{*}{$\begin{array}{c}\text { Dokladność oceny gęstości } \\
\text { objętościowej (RHOB): }\end{array}$} & \multicolumn{2}{|c|}{ Typ sondy pomiarowej } \\
\cline { 2 - 3 } & NGD & GGD \\
\hline \hline Piaskowce, wapienie, dolomity & $0,025 \mathrm{~g} / \mathrm{cm}^{3}$ & $0,015 \mathrm{~g} / \mathrm{cm}^{3}$ \\
\hline Łupki & $0,045 \mathrm{~g} / \mathrm{cm}^{3}$ & $0,015 \mathrm{~g} / \mathrm{cm}^{3}$ \\
\hline
\end{tabular}

dokładności przedstawia tabela 3 (Reichel et al., 2012).

\section{Analiza statystyczna uzyskanych danych $z$ omawianych otworów}

Przeanalizowano otrzymane wyniki obliczonych wartości ciepła radiogenicznego $\mathrm{w}$ pięciu otworach wiertniczych $\mathrm{z}$ basenu bałtyckiego.

Na rysunku 4 przedstawiono wykres średnich wartości obliczonego ciepła radiogenicznego Aśr dla utworów syluru i ordowiku: formacji łłowców z Pelplina, formacji iłowców z Pasłęka, ogniwa iłowców bitumicznych z Jantaru, formacji margli z Prabut, formacji iłowców z Sasina oraz formacji wapieni z Kopalina.

Najwyższymi wartościami średnimi charakteryzują się utwory ogniwa iłowców bitumicznych z Jantaru - wahają się między $2,32 \mu \mathrm{W} / \mathrm{m}^{3}$ w otworze $\mathrm{W}-1$ a $3,39 \mu \mathrm{W} / \mathrm{m}^{3}$ w otworze L-1. Maksymalne ciepło radiogeniczne osiąga w tych otworach wielkości od $3,77 \mu \mathrm{W} / \mathrm{m}^{3} \mathrm{w}$ otworze $\mathrm{W}-1$ do $5,00 \mu \mathrm{W} / \mathrm{m}^{3} \mathrm{w} \mathrm{L}-1$ i $5,09 \mu \mathrm{W} / \mathrm{m}^{3}$ w K-1 oraz $5,15 \mu \mathrm{W} / \mathrm{m}^{3}$ w O-2 i $5,40 \mu \mathrm{W} / \mathrm{m}^{3}$ w B-1. Bardziej zróżnicowana pod względem ciepła radiogenicznego jest formacja iłowców z Sasina. Średnie wartości są zawarte między $2,47 \mu \mathrm{W} / \mathrm{m}^{3} \mathrm{w} \mathrm{W}-1$ a $3,03 \mu \mathrm{W} / \mathrm{m}^{3}$ w K-1. Jednak maksymalne wartości są dużo wyższe i wynoszą od $3,50 \mu \mathrm{W} / \mathrm{m}^{3} \mathrm{w} \mathrm{W}-1$, poprzez $5,35 \mu \mathrm{W} / \mathrm{m}^{3}$ w O-2, $5,51 \mu \mathrm{W} / \mathrm{m}^{3}$ w B-1, 5,87 $\mu \mathrm{W} / \mathrm{m}^{3}$ w L-1, aż do najwyższej $9,75 \mu \mathrm{W} / \mathrm{m}^{3}$ w K-1.

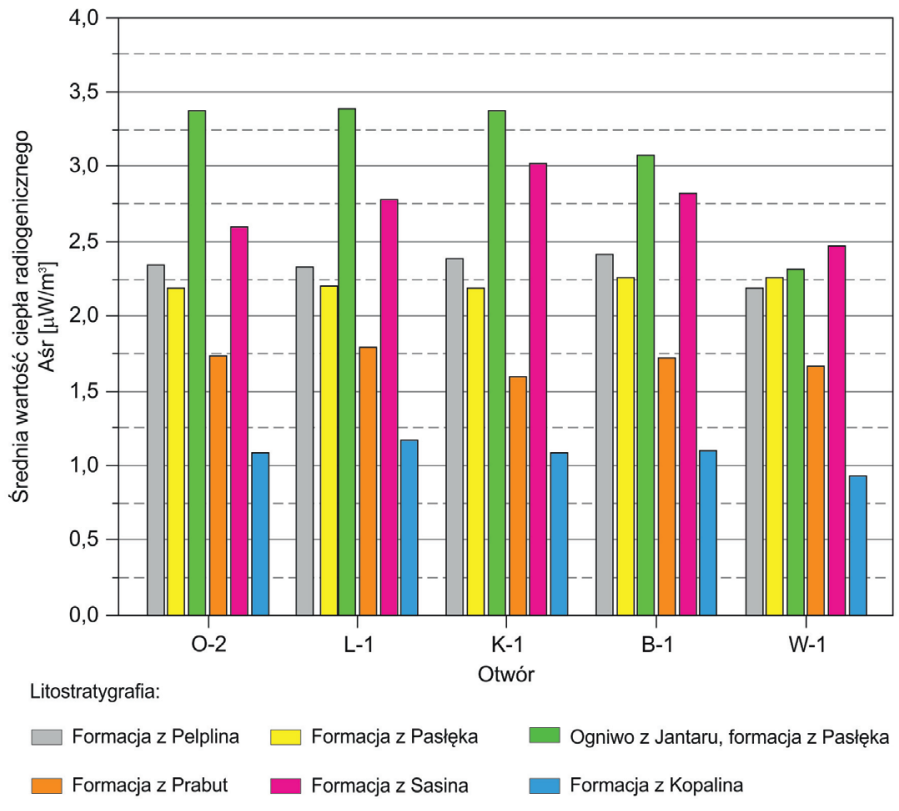

Rys. 4. Średnie wartości ciepła radiogenicznego obliczone dla utworów syluru i ordowiku w pięciu otworach basenu bałtyckiego Fig. 4. Average values of radiogenic heat calculated for the Silurian and Ordovician deposits in five wells from the Baltic Basin

Pozostałe utwory mają dość wyrównane wartości Aśr w ramach danej formacji. Najniższymi parametrami Aśr charakteryzują się wapienie z Kopalina - oscylują one wokół $1 \mu \mathrm{W} / \mathrm{m}^{3}$.

$\mathrm{W}$ analizowanych jednostkach litostratygraficznych zbadano również zależność średniego ciepła radiogenicznego od

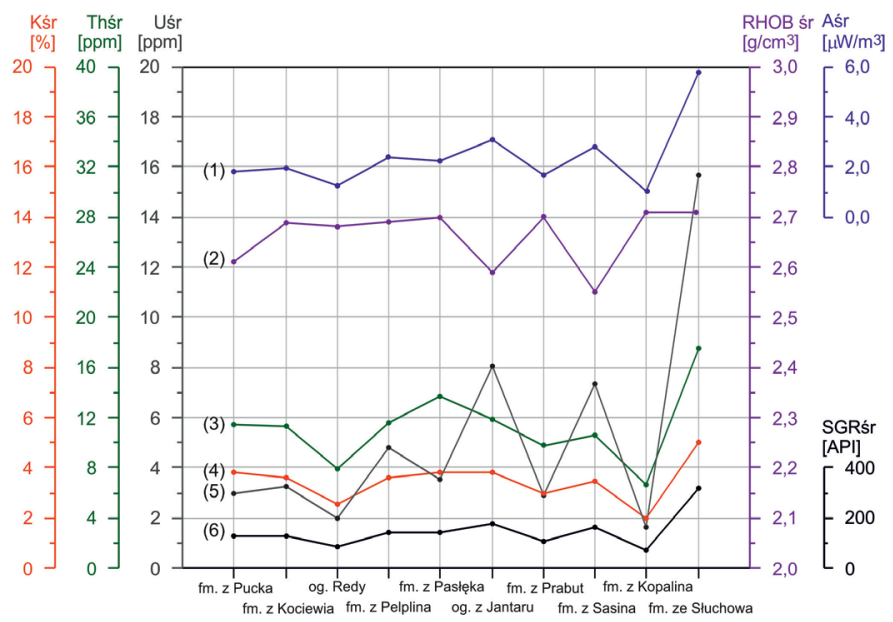

Rys . 5. Zestawienie średniej wartości ciepła radiogenicznego Aśr obliczonego dla danych z wszystkich otworów wiertniczych w poszczególnych jednostkach litostratygraficznych ze średnimi wartościami koncentracji potasu (Kśr), toru (Thśr), uranu (Uśr), gęstości objętościowej (RHOBśr) oraz spektrometrycznego profilowania gamma (SGRśr). Osie dla poszczególnych parametrów zostały tak dobrane, aby zwiększyć czytelność rysunku

Fig. 5. Comparison of mean radioactive heat values Aśr, calculated for data from all wells in each individual lithostratigraphic unit, with average values of potassium (Kśr), thorium (Thśr), and uranium (Uśr) concentrations, bulk density (RHOBśr) and spectral gamma ray log (SGRśr). The axes for individual parameters have been adjusted to increase the clarity of the figure 
poszczególnych emiterów naturalnej promieniotwórczości oraz gęstości objętościowej. Analizę wykonano dla omawianych otworów wiertniczych i przedstawiono na rysunku 5. Podwyższoną produkcję ciepła radiogenicznego obserwuje się w utworach ogniwa z Jantaru i formacji z Sasina, natomiast formacja ze Słuchowa wyróżnia się bardzo wysoką wartością Aśr, sięgającą prawie $6 \mu \mathrm{W} / \mathrm{m}^{3}$ (linia $\mathrm{nr} 1$ ). Niskimi wartościami ciepła radiogenicznego cechują się utwory mułowców wapnistych ogniwa Redy i wapienie formacji z Kopalina. Za wysoką wartość ciepła radiogenicznego w analizowanych skałach odpowiada głównie podwyższona koncentracja uranu (linia nr 5). Obecność kerogenu w obu perspektywicznych jednostkach obniża znacząco gęstość objętościową formacji (linia nr 2), ale wpływ uranu jest dominujący. W przypadku formacji węglanowych za niską produkcję ciepła radiogenicznego odpowiada niska koncentracja wszystkich izotopów pierwiastków promieniotwórczych (linie nr 3, 4 i 5). W formacji ze Słuchowa obserwuje się wyższą niż w pozostałych formacjach koncentrację K, Th i U - co ma odzwierciedlenie w wysokich wartościach profilowania gamma (linia nr 6) - i bardzo wysoką wartość ciepła radiogenicznego.

\section{Korelacje ciepła $z$ wybranymi parametrami}

Analizując ciepło radiogeniczne w powiązaniu $\mathrm{z}$ naturalną promieniotwórczością, można zaobserwować, że otwory O-2, K-1, B-1 i W-1 mają bardzo zbliżoną charakterystykę, znacząco odstają natomiast dane z otworu L-1 (rysunki 6a, b). Linia regresji dla L-1 w utworach syluru ma nieco inne nachylenie: dla danego zakresu profilowania gamma wartości ciepła radiogenicznego są wyraźnie podwyższone. Punkty na wykresie dla otworu B-1 leżą pomiędzy danymi z L-1 a danymi dla otworów K-1 i W-1.

Podobnie kształtują się relacje A vs SGR dla utworów ordowiku (rysunki 6c, d). Wykresy wykonane dla utworów ordowiku z rozdzieleniem na poszczególne jednostki litostratygraficzne pokazują, że grupa punktów odstająca od linii trendu w otworze L-1 należy do utworów formacji z Sasina (rysunek 6d). Analiza wykonana dla każdego otworu osobno pokazuje, że formacja ta cechuje się we wszystkich otworach (z wyjątkiem otworu W-1) podwyższoną naturalną promieniotwórczością, ale tylko w otworach leżących najbardziej na północy badanego obszaru, $\mathrm{tj}$. w otworach O-2 i L-1, obserwuje się podwyższone ciepło radiogeniczne. Świadczy to o istotnej zmienności lateralnej tego poziomu, uznawanego za sweet spot, i może wskazywać na obniżenie potencjału złożowego łupków gazonośnych w tej formacji na południowym wschodzie.

W tabeli 4 zestawiono równania regresji liniowej wyznaczonej dla utworów sylurskich i ordowickich dla poszczególnych otworów. Wartości współczynnika kierunkowego prostych są niemalże takie same w trzech otworach K-1, B-1 i W-1 dla skał syluru i ordowiku. Nieco odmienne relacje otrzymano w otworach O-2 (dla utworów ordowiku) i L-1 (dla utworów syluru), położonych najbardziej na północy analizowanego obszaru. $\mathrm{Na}$ zróżnicowany charakter relacji między naturalną promieniotwórczością a ciepłem radiogenicznym w całym sylurze mają wpływ osady formacji z Pucka. W przypadku skał ordowickich a)

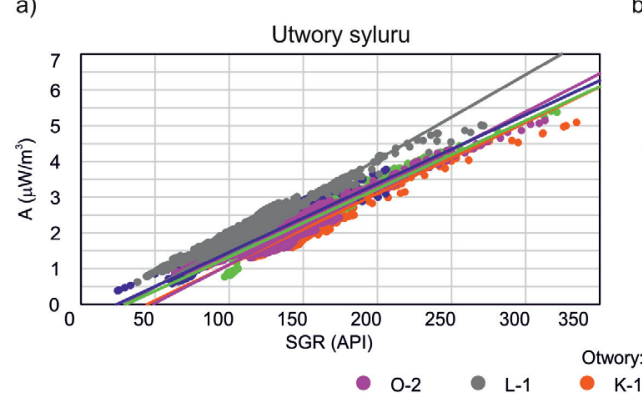

c)

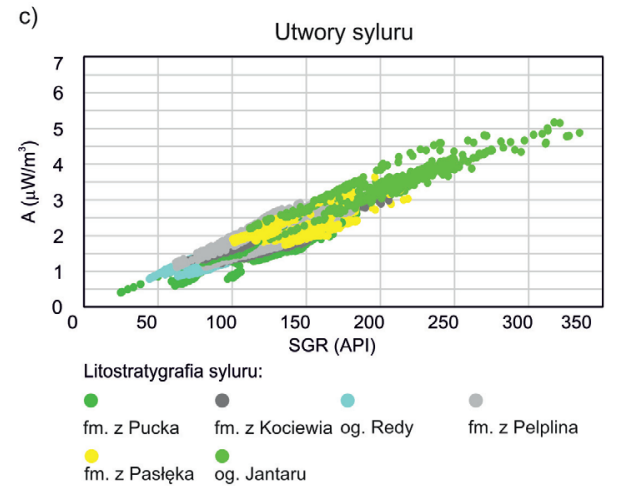

b)

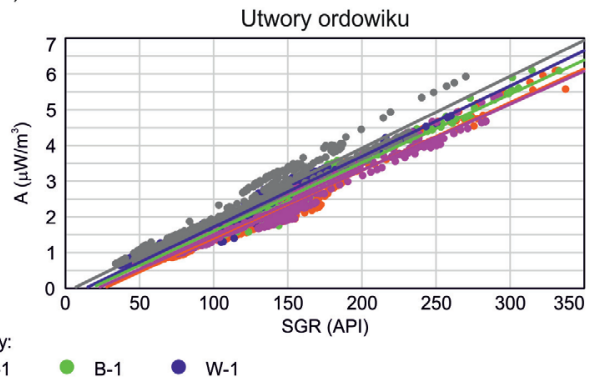

d)

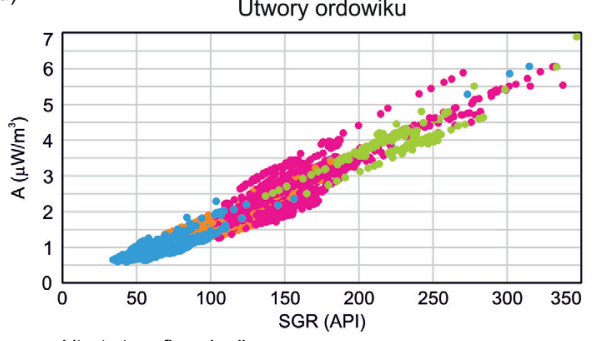

Litostratygrafia ordowiku:

fm. z Prabut fm. z Sasina fm. z Kopalina fm. ze Stuchowa
Rys. 6. Wykresy obrazujace relacje liniowe między spektrometrycznym profilowaniem gamma SGR (całkowitą naturalną promieniotwórczością) a ciepłem radiogenicznym A w pięciu analizowanych otworach $(a, b)$ : dla utworów syluru, począwszy od osadów formacji z Pucka aż do ogniwa z Jantaru, oraz dla utworów ordowiku, od osadów formacji z Prabut do formacji ze Słuchowa. Dolna część wykresu przedstawia te same dane, ale kolory punktów oznaczają wydzielenia litostratygraficzne (c, d)

Fig. 6. Plots showing linear relations between the spectral gamma ray log SGR (total natural radioactivity) and radiogenic heat $\mathrm{A}$ in five analyzed wells $(a, b)$ : for the Silurian deposits, from the Puck Formation to the Jantar Member; and for the Ordovician deposits, from the Prabuty Formation to the Słuchowo Formation. The bottom part of the figure presents the same data as the upper part, but the points are colored with regard to the lithostratigraphic division 
Tablica 4. Równania regresji liniowej dla utworów syluru i ordowiku w analizowanych otworach; $\mathrm{R}^{2}$ - współczynnik determinacji, RMSE - pierwiastek z błędu średniokwadratowego, A - ciepło radiogeniczne, SGR - całkowita naturalna promieniotwórczość z pomiaru spektrometrycznego

Table 4. Linear regression equations for the Silurian and Ordovician formations in the investigated wells; $\mathrm{R}^{2}$ - determination coefficient, RMSE - root-mean-square error, A - radiogenic heat, SGR - total natural radioactivity from spectral gamma ray log

\begin{tabular}{|c|c|c|c|c|c|}
\hline $\begin{array}{c}\text { Symbol } \\
\text { otworu }\end{array}$ & Stratygrafia & Równanie & $\mathbf{R}^{2}$ & RMSE & $\begin{array}{c}\text { Ilość } \\
\text { próbek }\end{array}$ \\
\hline \hline \multirow{2}{*}{ O-2 } & Sylur & $\mathrm{A}=0,021 \cdot \mathrm{SGR}-1,029$ & 0,903 & 0,139 & 16663 \\
\cline { 2 - 6 } & Ordowik & $\mathrm{A}=0,018 \cdot \mathrm{SGR}-0,436$ & 0,984 & 0,191 & 563 \\
\hline \multirow{2}{*}{$\mathrm{L}-1$} & Sylur & $\mathrm{A}=0,024 \cdot \mathrm{SGR}-0,702$ & 0,906 & 0,134 & 17297 \\
\cline { 2 - 6 } & Ordowik & $\mathrm{A}=0,020 \cdot \mathrm{SGR}-0,149$ & 0,980 & 0,208 & 587 \\
\hline \multirow{2}{*}{$\mathrm{K}-1$} & Sylur & $\mathrm{A}=0,020 \cdot \mathrm{SGR}-0,887$ & 0,767 & 0,142 & 18321 \\
\cline { 2 - 6 } & Ordowik & $\mathrm{A}=0,019 \cdot \mathrm{SGR}-0,534$ & 0,987 & 0,250 & 368 \\
\hline \multirow{2}{*}{$\mathrm{B}-1$} & Sylur & $\mathrm{A}=0,019 \cdot \mathrm{SGR}-0,580$ & 0,855 & 0,140 & 17684 \\
\cline { 2 - 6 } & Ordowik & $\mathrm{A}=0,019 \cdot \mathrm{SGR}-0,365$ & 0,992 & 0,177 & 316 \\
\hline \multirow{2}{*}{$\mathrm{W}-1$} & Sylur & $\mathrm{A}=0,019 \cdot \mathrm{SGR}-0,460$ & 0,910 & 0,109 & 18886 \\
\cline { 2 - 6 } & Ordowik & $\mathrm{A}=0,020 \cdot \mathrm{SGR}-0,305$ & 0,982 & 0,176 & 293 \\
\hline
\end{tabular}

odmienny charakter wykazują skały formacji z Sasina.

Dla utworów syluru i ordowiku sporządzono wykresy trójkątne K, Th i U oparte na pomiarach spektrometrycznych gamma w analizowanych otworach basenu bałtyckiego (rys. 7). Wykres trójkątny przedstawia względny procentowy udział poszczególnych pierwiastków promieniotwórczych w każdym punkcie pomiarowym. Względne proporcje każdego z trzech składników są tak normalizowane, aby ich suma dawała $100 \%$. Na wykresach uwzględniono także różne jednostki, w jakich wyrażone są zawartości U i Th (ppm) oraz K (\%), stosując przeliczenie $1 \mathrm{ppm}=10^{-4} \%$, tak jak zrobiono to w pracy Vilà et al. (2010).

$\mathrm{Na}$ wykresach trójkątnych przedstawiono odpowiednie proporcje występowania potasu, toru i uranu w badanych jednostkach litostratygraficznych. Wykresy wykonano oddzielnie dla formacji: z Pelplina, z Pasłęka (bez ogniwa z Jantaru), ogniwa z Jantaru, formacji z Prabut, formacji
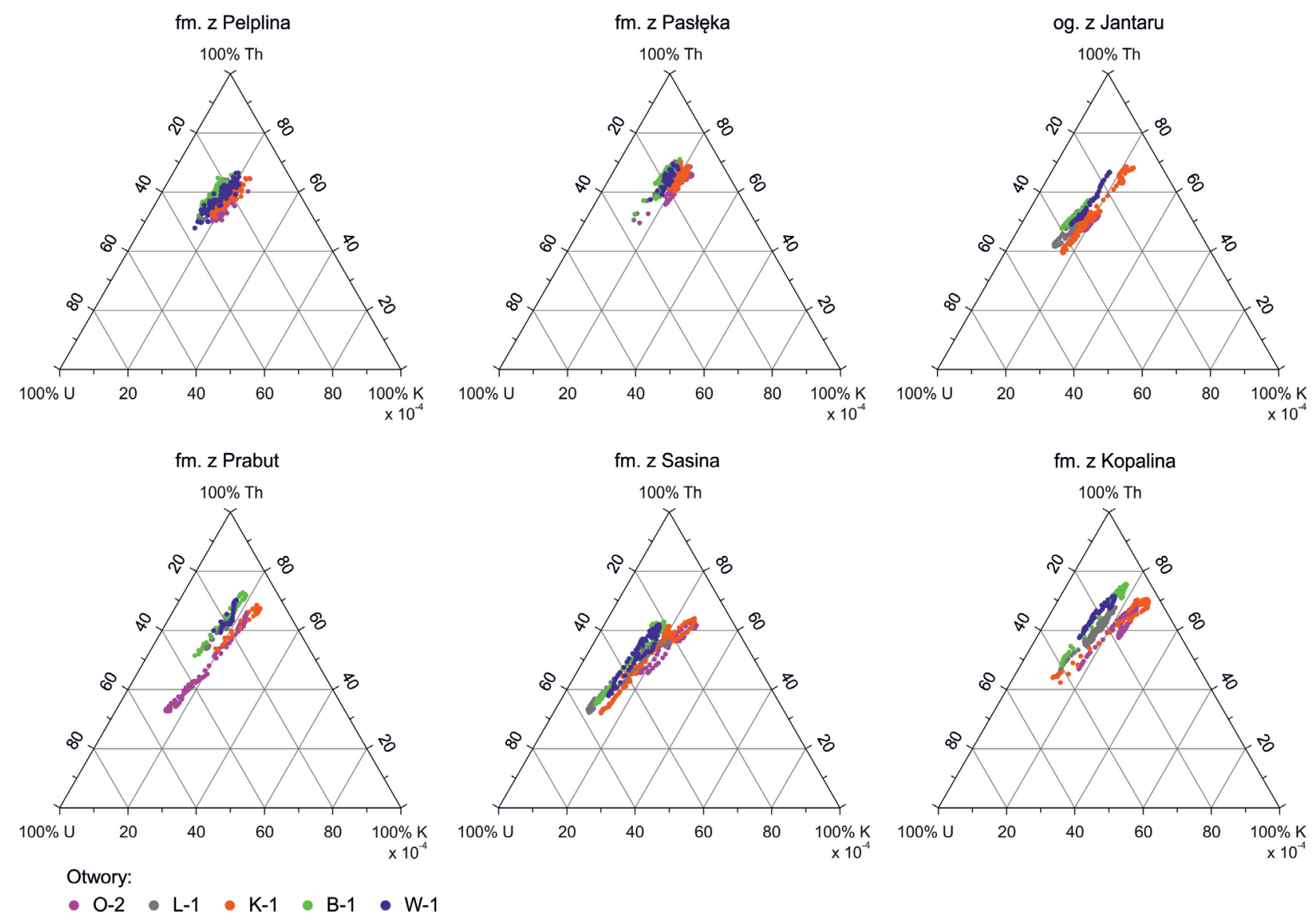

Rys. 7. Wykresy trójkątne dla K, Th i U sporządzone dla poszczególnych jednostek litostratygraficznych na podstawie danych ze wszystkich analizowanych otworów

Fig. 7. Ternary plots for K, Th and U prepared for individual litho stratigraphic units based on the data from all analyzed wells 
z Sasina oraz formacji z Kopalina, dla wszystkich pięciu otworów. Wykresy te umożliwiają oszacowanie wzajemnej relacji występowania poszczególnych izotopów promieniotwórczych. Szczegółowa analiza pozwala zauważyć pewne podobieństwo rozkładu punktów w grupach litologicznych odpowiadających analogicznym formacjom, chociaż istnieje pewna dyspersja danych.

Utwory formacji z Pelplina i Pasłęka cechują się podobnymi i w miarę stałymi proporcjami poszczególnych pierwiastków promieniotwórczych w każdym otworze. Zawartość K wynosi od kilkunastu do dwudziestu kilku procent, $\mathrm{U}$ - od 25\% do 50\%, a Th - między 50\% a 75\%.

W pozostałych formacjach obserwuje się większą zmienność względnej procentowej zawartości U i Th przy znacznie mniejszej zmienności K, oscylującej wokół 20\%. We wszystkich analizowanych otworach bardzo wysokie względne zawartości U występują w formacji z Sasina (do 60-70\%) oraz ogniwie z Jantaru (do 50-60\%). Pod względem podwyższonego udziału uranu wyróżnia się również formacja z Prabut w otworze O-2.

Najniższe zawartości uranu obserwuje się w otworze W-1 kosztem wzrostu udziału Th. Osady w otworze O-2 i K-1 generalnie cechują się podwyższoną zawartością izotopu potasu (punkty dla tych otworów są przesunięte w prawą stronę wykresów), szczególnie w przypadku wysokiej koncentracji toru. W utworach formacji z Sasina zaznacza się również nieco większy zakres zmienności zawartości potasu niż w pozostałych jednostkach litostratygraficznych.

\section{Relacja ciepla radiogenicznego}

z prędkościami fal podlużnych i gestościa

\section{objętościowa}

Na rysunku 8 zestawiono zależności pomiędzy obliczonymi wartościami ciepła radiogenicznego (A) i prędkościami fal podłużnych zarejestrowanych sondą dipolową z pełnym obrazem falowym (Vp_waveform). Kolejne wykresy pokazują podobnie układające się punkty odpowiadające utworom syluru i ordowiku w otworach L-1, K-1, O-2, B-1 i W-1.

Charakter zależności we wszystkich otworach jest bardzo zbliżony. Poszczególne jednostki litostratygraficzne zajmują bardzo podobne przedziały na wykresach. Tylko utwory a)

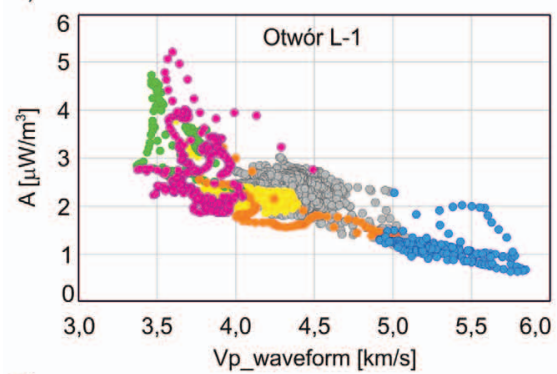

c)

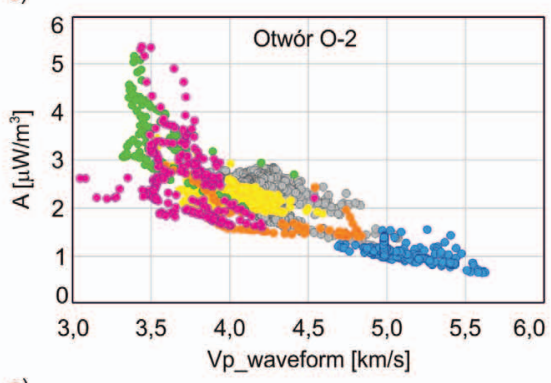

e)

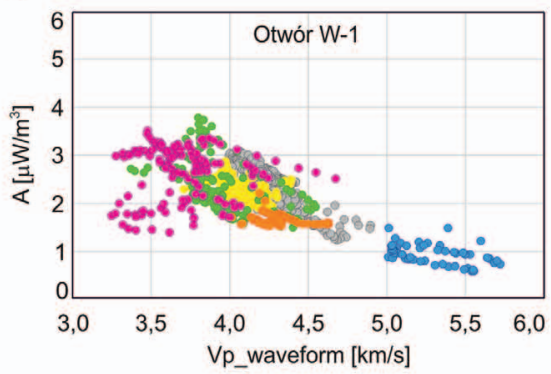

b)

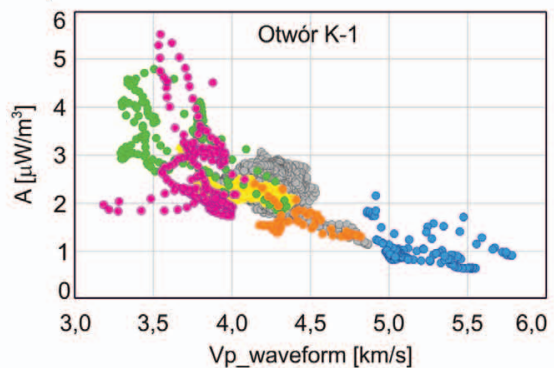

d)

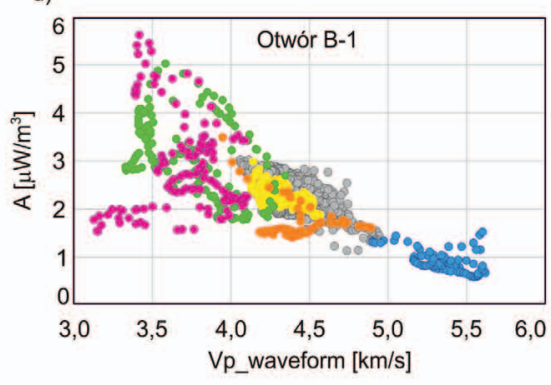

Litostratygrafia:

$\square$ Formacja z Pelplina

$\square$ Formacja z Pasłęka

- Ogniwo z Jantaru, formacja z Pasłęka

$\square$ Formacja z Prabut

- Formacja z Sasina

- Formacja z Kopalina

Rys. 8. Wykresy zależności ciepła radiogenicznego (A) w funkcji prędkości fali $\mathrm{P}$ (Vp_waveform) uzyskanych z profilowań akustycznych z pełnym obrazem falowym dla utworów syluru i ordowiku w otworach: a) L-1, b) K-1, c) O-2, d) B-1, e) W-1

Fig. 8. Plots of radioactive heat $(\mathrm{A})$ as a function of $\mathrm{P}$-wave velocity (VP_waveform) obtained from full wave sonic logs for the Silurian and Ordovician formations in wells: a) L-1, b) K-1, c) O-2, d) B-1, e) W -1

a)

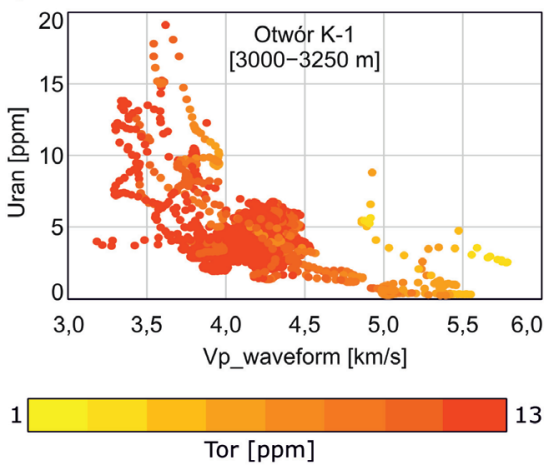

b)

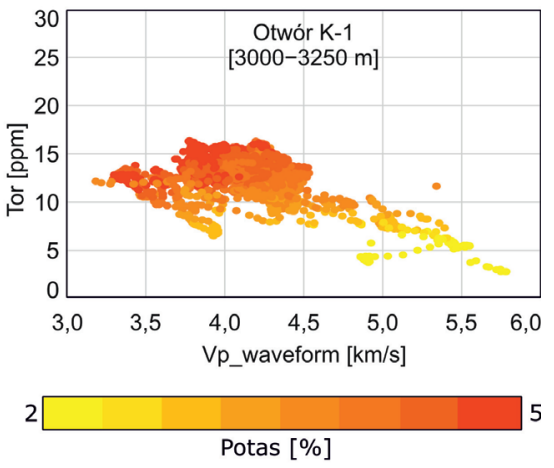

Rys. 9. Wykresy krzyżowe zawartości uranu (a) i zawartości toru (b) w funkcji prędkości fali P dla formacji syluru i ordowiku w otworze K-1

Fig. 9. Crossplots of uranium (a) and thorium (b) contents in function of $P$ wave velocity for the Silurian and Ordovician formations in the K-1 well 
się fal Vp i zawartości nie tylko toru i potasu, które są wskaźnikami minerałów ilastych, ale również uranu (rys. 9).

Jest to zrozumiałe, bowiem profilowania akustyczne wraz z profilowaniami oporności są wykorzystywane do obliczenia wartości TOC przy użyciu metody Passeya (Passey et al., 1990) czy też metody Carbolog (Carpentier et al., 1991; Ciechanowska i Kuśmierek, 1992; Sun et al., 2013; Gąsior et al., 2016). Na rysunku 10 przedstawiono położenie punktów dla głównych składników budujących skałę oraz linie łączące te punkty z punktem matrycy, w układzie współrzędnych $\Delta \mathrm{T}, 1 / \sqrt{ } \mathrm{Rt}$ (Carpentier et al., 1991).

Zróżnicowanie wartości czasów interwałowych fal P (DTP $\mathrm{w} \mu \mathrm{s} / \mathrm{m})$ pomiędzy punktem iłów a punktem kerogenu (OM) jest na tyle duże, że pociąga za sobą rozrzut punktów na wykresach A vs VP_waveform (rys. 8) w utworach, które charakteryzują się zmienną zawartością materii organicznej.

Należy wspomnieć, że w literaturze światowej można znaleźć związki pomiędzy ciepłem radiogenicznym a prędkościami fal podłużnych (A vs VP), jednak dotyczą one głównie skał metamorficznych czy też wulkanicznych, znacznie rzadziej osadowych (Hasterok et al., 2018).

Przeanalizowano również wzajemne relacje łączące ciepło radiogeniczne (A) z gęstością objętościową (RHOB) w poszczególnych otworach. Rysunek 11 pokazuje wybrane przykłady takich związków w otworach L-1 i K-1. Punkty odpowiadające tym samym formacjom zajmują podobne miejsca na wykresach, a całość danych wykazuje tendencję obniżania się ciepła radiogenicznego ze wzrostem gęstości objętościowej, analogicznie do relacji A vs Vp_waveform (rys. 8).

W tabeli 5 przedstawiono wartości gęstości objętościowej oraz prędkości fal P i S przyjmowane przy interpretacji danych geofizyki otworowej

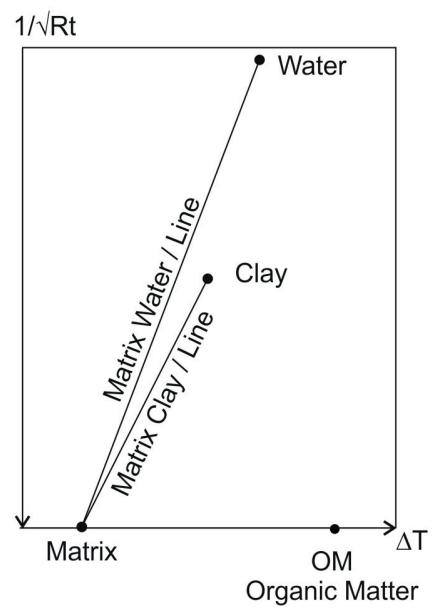

Rys. 10. Położenie punktów dla głównych składowych budujących skałę: szkielet skały (Matrix), woda (Water), ił (Clay) i materia organiczna (Organic Matter); oś $\mathrm{y}-\Delta \mathrm{T}$ (czas interwałowy fali $\mathrm{P} \mathrm{w}$ $\mu \mathrm{s} / \mathrm{m}$ ), oś x - 1/ل Rt (Rt - oporność w $\Omega \mathrm{m}$ ) (Carpentier et al., 1991)

Fig. 10. Location of points for the main rock components: rock skeleton (Matrix), Water, Clay and Organic Matter; $\mathrm{x}$ axis $-\Delta \mathrm{T}$ (wave propagation interval in $\mu \mathrm{s} / \mathrm{m})$, y axis $-1 / \sqrt{ } \mathrm{Rt}(\mathrm{Rt}-$ resistivity in $\Omega \mathrm{m})$ a)
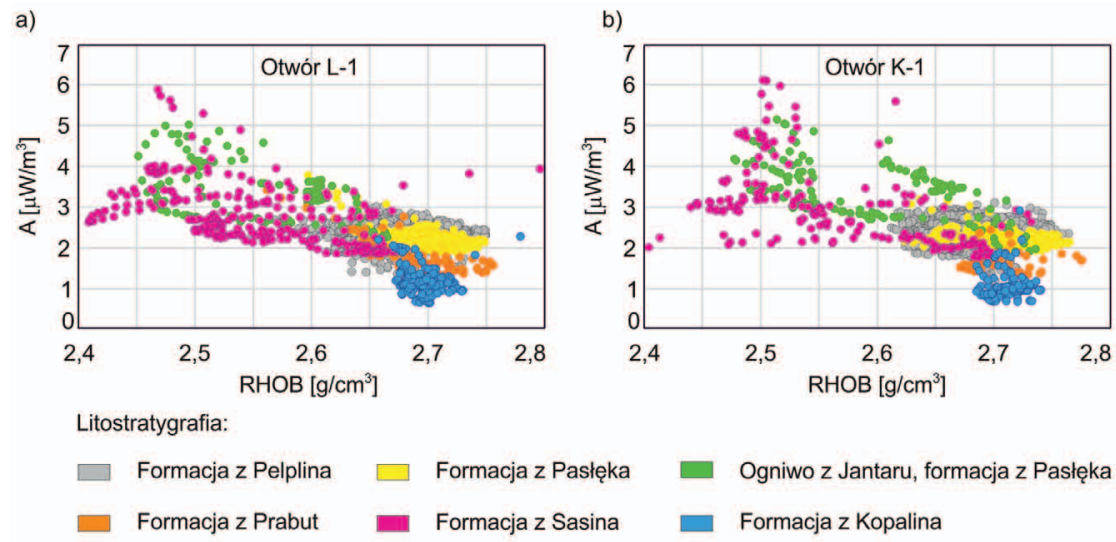

b)

Rys. 11. Ciepło radiogeniczne (A) w funkcji gęstości objętościowej (RHOB) w badanych formacjach w otworach: a) L-1 i b) K-1

Fig. 11. 11. Radiogenic heat (A) as a function of bulk density (RHOB) in the analyzed formations in wells a) L-1 and b) K-1

Tablica 5. Wartości gęstości objętościowej oraz prędkości fal P i S dla minerałów skałotwórczych spotykanych w łupkach gazonośnych

Table 5. Values of bulk density and $P$ and $S$ wave velocities of the main minerals found in gas-bearing shales

\begin{tabular}{|c|c|c|c|c|c|c|}
\hline \multirow{2}{*}{ Mineral/medium } & RHOB $_{\text {ma }}$ & $\mathbf{V} \mathbf{P}_{\mathrm{ma}}$ & DTP $_{\text {ma }}$ & $\mathrm{VS}_{\mathrm{ma}}$ & DTS $_{\text {ma }}$ & \multirow{2}{*}{ Opis } \\
\hline & {$\left[\mathrm{g} / \mathrm{cm}^{3}\right]$} & {$[\mathrm{km} / \mathrm{s}]$} & {$[\mu \mathrm{s} / \mathrm{m}]$} & {$[\mathrm{km} / \mathrm{s}]$} & {$[\mu \mathrm{s} / \mathrm{m}]$} & \\
\hline Kwarc & 2,65 & $\begin{array}{l}5,78 \\
6,01^{*}\end{array}$ & $\begin{array}{l}173,0 \\
166,4\end{array}$ & $\begin{array}{l}3,876 \\
4,06^{*}\end{array}$ & $\begin{array}{l}258,0 \\
246,1\end{array}$ & $\begin{array}{l}\text { Eastwood. Castagna, } 1986 \\
{ }^{*} \text { Ahrens, } 1995\end{array}$ \\
\hline Wapienie & 2,71 & 6,40 & 156,0 & 3,22 & 310,6 & Halliburton,1992 \\
\hline Skalenie (albit) & 2,62 & 6,21 & 161,0 & 3,58 & 279,3 & Halliburton,1992 \\
\hline Piryt & $4,92^{*}$ & $7,86^{*}$ & 127,2 & $5,0^{*}$ & 200,0 & $\begin{array}{l}\text { Halliburton, } 1992 \\
{ }^{*} \text { Ahrens, } 1995\end{array}$ \\
\hline Ił & $\begin{array}{l}2,65 \\
2,60\end{array}$ & $\begin{array}{c}4,11 \\
3,175\end{array}$ & $\begin{array}{l}243,3 \\
315,0\end{array}$ & $\begin{array}{c}2,30 \\
1,644\end{array}$ & $\begin{array}{l}434,8 \\
608,3\end{array}$ & $\begin{array}{l}\text { Illit/smektyt osady wenloku: } \\
\text { Bała, 2015; Bała, } 2007\end{array}$ \\
\hline Kerogen & $\begin{array}{l}1,25 \\
1,30\end{array}$ & 2,8 & 357,1 & 1,6 & 625,0 & Vernik i Liu, 1997 \\
\hline
\end{tabular}


dla charakterystycznych składników skał łupków gazonośnych (fragment tabeli z Bała, 2015).

\section{Podsumowanie i wnioski}

Obliczono wartości ciepła radiogenicznego dla utworów syluru i ordowiku w otworach L-1, K-1, O-2, B-1 i W-1 położonych w basenie bałtyckim. W tym celu wykorzystano spektrometryczne pomiary geofizyki otworowej i znany wzór Rybacha (Rybach, 1986).

Najwyższymi wartościami średnimi charakteryzują się utwory ogniwa iłowców bitumicznych z Jantaru - wahają się one między $2,32 \mu \mathrm{W} / \mathrm{m}^{3}$ w otworze $\mathrm{W}-1$ a $3,39 \mu \mathrm{W} / \mathrm{m}^{3}$ w otworze O-2 - oraz utwory formacji iłowców z Sasina, dla których średnie wartości są zawarte między $2,47 \mu \mathrm{W} / \mathrm{m}^{3} \mathrm{w}$ otworze $\mathrm{W}-1$ a $3,02 \mu \mathrm{W} / \mathrm{m}^{3} \mathrm{w}$ otworze K-1. Formacja ta jest też najbardziej zróżnicowana. Maksymalne wartości ciepła radiogenicznego są znacznie wyższe w obu formacjach, co wiąże się z podwyższoną w nich zawartością materii organicznej (sweet spots).

Anomalnie wysokie wartości Aśr wykazuje formacja iłowców ze Słuchowa, zawierająca iłowce i mułowce z licznym rozproszonym glaukonitem, a w części stropowej cienkie wkładki bentonitów.

Obserwuje się silne korelacje pomiędzy ciepłem radiogenicznym (A) i całkowitą promieniotwórczością (SGR) zarówno w utworach syluru, jak i ordowiku. Współczynniki determinacji $\mathrm{R}^{2}$ wahają się od 0,767 do 0,910 dla łupków sylurskich i od 0,980 do 0,992 dla osadów ordowiku.

Skonstruowane wykresy trójkątne pozwalają na oszacowanie proporcji występowania izotopów promieniotwórczych $U$, Th i K w badanych formacjach i porównanie ich w poszczególnych otworach.

Korelacja ciepła radiogenicznego z parametrami skał wyznaczonymi na podstawie innych profilowań, szczególnie akustycznych, może dostarczyć unikalnych informacji wykorzystywanych w modelowaniach basenów naftowych.

Podziękowania: Autorki dziękują Polskiemu Górnictwu Naftowemu i Gazownictwu S.A. w Warszawie za udostępnienie danych wykorzystanych w niniejszym artykule w ramach projektu Blue Gas MWSSSG Polskie Technologie dla Gazu Łupkowego, zadanie 10, realizowanego w latach 2013-2017. Praca była częściowo finansowana przez Wydział Geologii, Geofizyki i Ochrony Środowiska ze środków przeznaczonych na działalność naukową w latach 2018 i 2019 (nr 16.16.140.315).

\section{Literatura}

Ahrens T.J. (ed.), 1995. A handbook of physical constants. American Geophysical Union, Washington, DC.
Bała M., 2007. Wpływ obecności iłów, porowatości oraz nasycenia porów wodą i gazem na parametry sprężyste skał zbiornikowych określanych na podstawie teoretycznych modeli ośrodków porowatych i danych geofizyki wiertniczej. Przegląd Geologiczny, 55(1): 46-53.

Bała M., 2015. Parametry sprężyste łupków zawierających materię organiczną określone na podstawie teoretycznych relacji Biota-Gassmana i Kustera-Toksöza. Nafta-Gaz, 12: 1005-1016.

Bała M., Waliczek M., 2012. Obliczanie ciepła radiogenicznego osadów cechsztynu i karbonu na podstawie danych geofizyki otworowej w rejonie rafy Brońsko. Przegląd Geologiczny, 60(3): 155-163.

Bała M., Witek K., 2011. Determination of Radioactive Heat Production from Well Logging for Sedimentary Rocks in Miocene Formations in Poland. $1^{\text {st }}$ Sustainable Earth Sciences Conference \& Exhibition - Technologies for Sustainable Use of the Deep Sub-Surface. Valencia, Spain, 8-10 November 2011. Conference Proceedings, P18: 431-435.

Bücker Ch., Rybach L., 1996. A simple method to determine heat production from gamma-ray logs. Marine and Petroleum Geology, 13(4): 373-375.

Carpentier B., Huc A.Y., Bessereau G., 1991. Wireline logging and source rocks - estimation of organic carbon content by the CARBOLOG method. The Log Analyst, 32: 279-297.

Cermak V., Bodri L., Rybach L., Buntebarth G., 1990. Relationship between seismic velocity and heat production: comparison of two sets of data and test of validity. Earth and Planetary Science Letters, 99: 48-57.

Ciechanowska M., Gąsior I., 2000. Ciepło radiogeniczne emitowane przez utwory mioceńskie przedgórza Karpat. Nafta-Gaz, 4: 197-208.

Ciechanowska M., Kuśmierek J., 1992. Ocena potencjału macierzystości perspektywicznych formacji ropogazonośnych metodami geofizyki wiertniczej. Nafta-Gaz, 11-12: 269-277.

Dokumentacje wynikowe otworów L-1, O-2, K-1, B-1, W-1. Badania laboratoryjne, wyniki interpretacji. Archiwum PGNiG, Warszawa.

Eastwood R.L., Castagna J.P., 1986. Interpretation of Vp/Vs ratios from sonic logs. [W:] Danbom S.H., Domenico S.N. (eds.), Shear-wave exploration, SEG. 139-153.

Ellis D.V., Singer J.M., 2008. Well Logging for Earth Scientists. 2nd Edition. Springer, Dordrecht.

Förster A., Förster H.J., 2000. Crustal composition and mantle heat flow: implications from surface heat flow and radiogenic heat production in the Variscan Erzgebirge (Germany). Journal of Geophysical Research, 105(27): 917-938.

Gąsior I., Skupio R., Dohnalik M., 2016. Metodyka wyznaczania zawartości substancji organicznej w utworach niższego paleozoiku i karbonu dla archiwalnych otworów wiertniczych. Przegląd Geologiczny, 64(12): 987-994.

Halliburton, 1992. Log Interpretation Charts. Halliburton, Houston, TX. Hasterok D., Gard M., Webb J., 2018. On the radiogenic heat production of metamorphic, igneous and sedimentary rocks. Geoscience Frontiers, 9: 1777-1794.

Jarzyna J., Bała M., Zorski T., 1999. Metody geofizyki otworowej, pomiary i interpretacja. Wydawnictwa AGH, Kraków.

Keen C.E., Levis T., 1982. Measured radiogenic heat production in sediments from continental margin of eastern North America: implications for petroleum generations. AAPG Bulletin, 66: 1402-1407.

Kotarba M.J., Peryt T.M., Kosakowski P., Więcław D., 2006. Organic geochemistry, depositional history and hydrocarbon generation modeling of the Upper Permian-Kupferschiefer and Zechstein 
Limestone strata in south-west Poland. Marine and Petroleum Geology, 23(3): 371-386.

Krawiec J., 2007. Correlation radiogenic heat production with presence of organic matter - qualitative analysis. Near Surface Geoscience $2007-13^{\text {th }}$ European meeting of environmental and engineering geophysics, 3-5 September 2007, Istanbul, Turkey. Extended abstracts \& exhibitors catalogue.

Mccay A.T., Harley T.L., Younger P.L., Sanderson D.C.W., Cresswell A.J., 2014. Gamma-ray Spectrometry in Geothermal Exploration: State of the Art Techniques, Energies, 7: 4757-4780.

McKenna T.E., Sharp J.M., 1998. Radiogenic heat production in sedimentary rocks of the Gulf of Mexico basin, South Texas. AAPG Bulletin, 82: 484-496.

Modliński Z., Szymański B., 1997. The Ordovician lithostratigraphy of the Peribaltic Depression (NE Poland). Geological Quarterly, 41(3): 273-288.

Modliński Z., Szymański B., Teller L., 2006. Litostratygrafia syluru polskiej części obniżenia perybałtyckiego - część lądowa i morska (N Polska). Przegląd Geologiczny, 54(9): 787-796.

Norden B., Förster A., 2006. Thermal conductivity and radiogenic heat production of sedimentary and magmatic rocks in the Northeast German Basin. AAPG Bulletin, 90: 939-962.

Passey Q.R., Creaney S., Kulla B., Moretti F.J., Stroud J.D., 1990. A Practical Model for Organic Richness from Porosity and Resistivity Logs. AAPG Bulletin, 74(12): 1777-1794.

Plewa S., 1988. Wyniki badań ciepła radiogenicznego skał obszaru Polski. Zeszyty Naukowe AGH, Geofizyka Stosowana, 1: 125-137.

Podhalańska T., Waksmundzka M.I., Becker A., RoszkowskaRemin J., 2016. Rozpoznanie stref perspektywicznych występowania niekonwencjonalnych złóż węglowodorów w Polsce - nowe wyniki oraz dalsze kierunki badań. Przegląd Geologiczny, 64(12): 953-962.

Poprawa P., 2010. Potencjał występowania złóż gazu ziemnego w łupkach dolnego paleozoiku w basenie bałtyckim i lubelsko-podlaskim. Przeglad Geologiczny, 58(3): 226-249.

Porębski S.J., Prugar W., Zacharski J., 2013. Łupki sylurskie platformy wschodnioeuropejskiej w Polsce - wybrane problemy poszukiwawcze. Przeglad Geologiczny, 61(8): 468-477.

Reichel N., Evans M., Allioli F., Mauborgne M.L., Nicoletti L., Haranger F., Laporte N., Stoller Ch., Cretoiu V., El Hehiawy E., Rabrei R., 2012. Neutron-gamma density (NGD): principles, field test results and log quality control of a radioisotope-free bulk density measurement. SPWLA $53^{\text {rd }}$ Annual Logging Symposium, 16-20 June, Cartagena, Colombia.
Rybach L., 1986. Amount and significance of radioactive heat sources in sediments. [W:] Burrus J. (red.), Thermal Modeling of Sedimentary Basins, Collection Colloques et Seminares 44. Technip, Paris (France), 1. IFP Exploration research conference, Carcans (France), 3-7 Jun 1985, Paris: 311-322.

Schlumberger, 2004. Spectral gamma ray tools. $<$ https://www.slb. com/ /media/Files/evaluation/product_sheets/wireline_open_hole/ petrophysics/gamma/sgrt.pdf $>$ (dostęp: maj 2019).

Sikorska-Jaworowska M., Kuberska M., Kozłowska A., 2016. Petrografia i mineralogia łupków niższego paleozoiku kratonu wschodnioeuropejskiego oraz piaskowców karbonu podłoża monokliny przedsudeckiej. Przeglad Geologiczny, 64(12): 963-967.

Slagstad T., 2008. Radiogenic heat production of Archaean to Permian geological provinces in Norway. Norwegian Journal of Geology, 88: 149-166.

Sun S.Z., Sun Y., Sun C., Liu L., Dong N., 2013. Method of calculating total organic carbon from well logs and its application on rock's properties analysis. Conference: GeoConvention 2013: Integration, Calgary, 6-12 May 2013. http://www.searchanddiscovery.com/documents/2014/41372sun/ndx_sun.pdf.

Vernik L., Liu X., 1997. Velocity anisotropy in shales: A petrophysical study. Geophysics, 62(2): 521-532.

Vilà M., Fernández M., Jiménez-Munt I., 2010. Radiogenic heat production variability of some common lithological groups and its significance to lithospheric thermal modeling. Tectonophysics, 490: $152-164$.

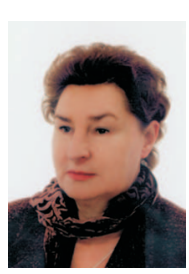

Prof. dr hab. inż. Maria BAŁA

Akademia Górniczo-Hutnicza im. Stanisława

Staszica w Krakowie, Wydział Geologii, Geofizyki i Ochrony Środowiska, Katedra Geofizyki.

al. Mickiewicza 30

30-059 Kraków

E-mail:bala@agh.edu.pl

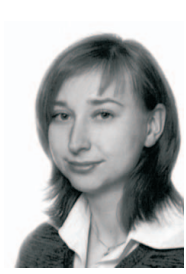

Dr inż. Kamila WAWRZYNIAK-GUZ

Adiunkt w Katedrze Geofizyki na Wydziale Geologii, Geofizyki i Ochrony Środowiska Akademia Górniczo-Hutnicza im. Stanisława Staszica w Krakowie

al. Mickiewicza 30, 30-059 Kraków

E-mail:wawrzyni@agh.edu.pl 